\title{
ANALISIS PROSES METAKOGNISI DALAM PEMECAHAN MASALAH MATEMATIKA DITINJAU DARI GAYA KOGNITIF
}

\author{
Isabela Freningsi Kidi Sili' ${ }^{1}$ Dian Fitri Argarini ${ }^{2}$ \\ 1.2 IKIP Budi Utomo Malang \\ kejora.subuh14@gmail.com
}

\begin{abstract}
Abstrak
Tujuan dari penelitian ini adalah untuk mengetahui proses metakognisi siswa SMP Islam Baiturrohmah Malang kelas VIII kelompokgaya kognitif FD dan FI dalam pemecahan masalah matematika materi bangun ruang sisi datar. Penelitian ini merupakan penelitian deskriptif kualitatif dan pemilihan subjek dalam penelitian ini adalah purposive sampling. Pada penelitian ini diambil dua subjek, yaitu masing-masing satu siwa pada subjek FDdan subjek FI. Subjek dipilih menggunakan tes GEFT. Instrumen yang digunakan tes pemecahan masalah danpedoman wawancara.Hasil penelitian sebagai berikut (1) proses metakognisi siswa FD dalam pemecahan masalah pada indikator awareness dapat dilihat subjek mampu menyebutkan apa yang ditanyakan dari soal secara lengkap, namun keliru dalam menuliskan apa yang diketahui. Pada indikator regulating subjek sudah mampu menentukan rencana dan melaksanakan dengan benar. Pada indikator evaluating subjek sudah bisa memeriksa kembali jawaban yang sudah dikerjakan dan memberikan kesimpulan, (2) proses metakognisisiswa FI dalam pemecahan masalah pada indikator awareness dapat dilihat subjek sudah mampu menyebutkan apa yang diketahui dan ditanyakan dari soal dengan baik. Pada indikator regulating subjek mampu mengatur rencana dan melaksanakan dengan benar. Pada indikator evaluating subjek belum mampu memeriksa kembali jawaban dan menarik kesimpulan.
\end{abstract}

Kata kunci: proses metakognisi, pemecahan masalah, gaya kognitif

\begin{abstract}
The purpose of this research was to determine the metacognition process of students in Baiturrohmah Malang Islamic Junior High School Class VIII which have a field dependent (FD) and field independent (FI) cognitive style in solving mathematical problems in solid geomethry topic. This type of research is qualitative descriptive research with purposive sampling method. The subject were 1 FD and 1 FI. The subjects were selected by GEFT test. The instrumentsused in this research are broblem solving test and interview guidelines. The resultsare (1) the process of metacognition
\end{abstract}


of FD subject in problemsolving, on awareness indicator, it can be seen that subject was able to mention what was ask of the question completely, subject was mistaken in writing down what was known. On regulating indicator the subject has been able to determine the plan and carry out the plan correctly. The indicator evaluating the subject has been able to re-examine the answers and give the conclusion, (2) the process of metacognition of FI subject in problem solving. In the awareness indicator, it can be seen that subject has been able to mention what is known and asked about the problem well. Regulating indicatorthe subject was able to arrange the plan and carry out the plan correctly. evaluating indicator the subject has not been able to re-examine the answer that have been done but have not arrived at conclusions.

Keywords: metacognition process, problem solving, cognitive style

\section{PENDAHULUAN}

Kemampuan pemecahan masalah adalah salah satu skill yang perlu diasah oleh siswa terlebih pada mata pelajaran matematika. Banyak ahli yang mengatakan bahwa sangat penting belajar pemecahan masalah dalam matematika. Banyak hasil penelitian yang menunjukkan dapat membantu para siswa dalam meningkatkan daya analitis mereka. Siswa dituntut untuk memiliki kemampuan berikir tinggi untuk lebih memahami masalah dan menentukan penyelesaiannya. Tidak hanya sekedar berpikir namun berpikir tentang proses berpikir itu sendiri, berpikir seperti ini disebut dengan metakognitif atau metakognisi.

Kuhn (dalam Murti, 2011) menyatakan bahwa metakognisi adalah kemampuan seseorang dalam mengatur pola "berpikir mengenai berpikir" yang dilakukan secara sadar dan dengan proses yang sederhana. Young (dalam Murti, 2011) mengemukakan bahwa proses metakognisi sebagai kemampuan untuk mengontrol proses berpikir sendiri yaitu terdiri dari: a). monitoring terhadap strategi dan proses berpikir yang digunakan dalam mengerjakan tugas, b). pencarian alternative pencarian tugas, c). pengecekan ketepatan dan kerasionalan dari jawaban. Sedangkan menurut Purnomo (2017) karakteristik bproses metakognisi antara lain yaitu awareness, regulation, dan evaluation. Pola berpikir masingmasing individu pasti berbeda karena masing-masing memiliki karakteristik atau ciri khas atau gaya dalam memahami hal. Gaya kognitif adalah salah satu hal yang mempengaruhi bagaimana pola pikir seseorang. 
Witkin (1977) menyatakan bahwa gaya kognitif adalahkarakteristik fungsi di mana kita mengungkapkan seluruh aktivitas persepsi dan intelektual kita dengan cara yang sangat konsisten dan meresap.Sedangkan Tennant (dalam Saputro, 2011) mendefinisikan bahwa gaya kognitif adalah pendekatan dari suatu individu dalam memanajemen dan memproses informasi yang telah diperoleh . Dalam penelitian ini gaya kognitif dibedakan menjadi dua kelompok yaitu field dependent(FD)dan field independent(FI). Balchin dan Jackson (2009) menyatakan bahwa gaya kognitif dan pembelajaran dapat digunakan untuk memprediksi pendekatan pengajaran seperti apa yang paling efektif untuk individu atau kelompok. Bagian singkat ini berfokus pada gaya kognitif yang mungkin berguna untuk dipertimbangkan saat merancang pengajaran untuk kreativitas.

Penelitian yang dilakukan oleh Ngilawajan (2013) dalam penelitiannya yang berjudul Proses Berpikir Siswa SMA dalam Memecahkan Masalah Matematika Materi Himpunan Ditinjau dari Gaya Kognitif Field Independent dan Field Dependent. Dalam penelitian ini menunjukan bahwa adanya perbedaan yang signifikan antara kedua subjek pada langkah memahami masalah, yaitu subjek FI memahami masalah lebih baik dibandingkan dengan subjek FD. Selain itu, subjek FI menunjukan pemahaman yang baik terhadap konsep turunan bila dibandingkan dengan subjek FD.

Penelitian yang dilakukan oleh Pratiwi (2014) mendeskripsikan bahwa pada subjek yang memiliki kemampuan tinggi, proses metakognisi sudah terlihat baik namun ada kekurangan pada langkah pemeriksaan ulang dimana siswa hanya melihat tanpa memeriksa kembali pekerjaan. Pada subjek dengan kemampuan sedang, subjek mampu melakukan pemahaman dengan memenuhi aspek perencanaan, pemantauan, dan mengevaluasi. Pada tahap penyusunan dan pelaksanaan, subjek melewatkan aspek evaluasi, sedangkan pada tahap evaluasi subjek hanya memeriksa kembali jawaban.Pada subjek kemampuan matematika rendah pasa proses pemahaman sudah muncul aspek perencanaan dan pemantauan, pada proses penyusunan dan pelaksanaan terlihat aspek perencanaan dan pemantauan. Sedangkan pada proses pemeriksaan ulang subjek hanya mengevaluasi.Proses seseorang dalam menyelesaiakan masalah (persoalan yang tidak biasa) disebut dengan kemampuan pemecahan masalah. Proses ini digunakan oleh siswa untuk menyelesaikan masalah matematika. Jadi, dalam menyelesaikan masalah 
matematika siswa, seorang guru juga harus memerhatikan gaya kognitif siswa dalam melaksanakan pembelajaran. Pemahaman guru terhadap gaya belajar siswa bisa dimanfaatkan guru untuk menyusun perencanaan pembelajaran yang sesuai sehingga tujuan pembelajaran bisa terpenuhi.

Berhubung siswa tidak dapat memroses semua informasi pada tingkat kedalaman yang sama, maka siswa memerlukan fungsi eksekutif untuk mengawasi proses pengkodean, pentransformasian, pemrosesan, pelacakan kembali, pengiriman, serta penggunaan suatu informasi.

Berdasarkan hasil uraian diatas maka peneliti termotivasi melakukan penelitian dengan judul "Analisis Proses Metakognisi Siswa Dalam Pemecahan Masalah Matematika pada Materi Bangun Ruang Sisi Datar Ditinjau dari Gaya Kognitif bagi Siswa Kelas VIII SMP Islam Baiturrohmah Malang."

\section{METODE PENELITIAN}

Jenis penelitian ini merupakan deskriptif kualitatif. Penelitian ini bertujuan untuk mengetahui proses metakognisi siswa SMP Islam Baiturrohmah Malang Kelas VIII kelompok gaya kognitif FDdan FI dalam memecahkan masalah matematika pada materi bangun ruang sisi datar.

Subjek dalam penelitian ini adalah siswa kelas VIII SMP Islam
Baiturrohmah Malang yang beralamat di jalan Ciliwung, kecamatan Belimbing, Kabupaten Malang. Penelitian ini berjalan selama satu minggu dimulai dari tanggal 18 Juli sampai 28 Juli 2018. Pengambilan subjek yang terdiri dari 2 siswa, dengan 1 siswa bergaya kognitif field dependent dan 1 siswa bergaya kognitif field independent. Alat pengumpul data dalam penelitian ini adalah tes pemecahan masalah dan pedoman wawancara.

Teknik analisis data dalam penelitian ini yaitu data yang telah diperoleh akan dianalisis secara deskriptif. Analisis data yang dilakukan dalam penelitian ini meliputi, tahap pengumpulan data, penyajian data, reduksi data, dan penarikan kesimpulan (Sugiyono, 2008)

\section{HASIL DAN PEMBAHASAN}

Pemilihan subjek penelitian dilakukan pada siswa yang bergaya kognitif field dependent dan siswa bergaya kognitif field independent, diperoleh dari tes gaya kognitif GEFT (Group Embedded Figures Test) yang dilaksanakan pada tanggal 27 Juli 2018.

Data dalam penelitian ini adalah proses metakognisi siswa dalam pemecahan masalah matematika. Pada pengambilan data pertama subjek diberikan soal tes pemecahan masalah tentang bangun ruang sisi datar. 
Selanjutnya dilakukan pengambilan data kedua dengan memberikan tes wawancara terkait tes pemecahan masalah. Hal ini bertujuan untuk memperoleh data yang valid dengan cara triangulasi teknik.

Subjek Bergaya Kognitif Field Dependent

\section{Indikator Awareness}

Pada indikator metakognisi awareness dilihat dari subjek bisa menentukan apa yang diketahui dan ditanyakan.Pada tahap ini subjek memilikiawareness yang baik, bisa dilihat pada hasil jawaban subjek, namun subjek masih melakukan kesalahan dengan menuliskan apa yang diketahui.

\section{Indikator Regulating}

Pada indikator metakognisi regulating dilihat dari subjek bisa menentukan rencana dan melaksanakan rencana tersebut.Pada tahap ini $\mathrm{Pu}$ memiliki regulating yang baik, bisa dilihat dari jawaban $\mathrm{Pu}$ bahwa $\mathrm{Pu}$ menentukan rencana dan melakukan rencana tersebut dengan baik dan benar.

\section{Indikator Evaluating}

Pada tahap Evaluating dilihat dari subjek dapat memeriksa kembali atau mengoreksi kembali jawaban yang sudah ada dan subjek bisa menarik kesimpulan.Pada tahap ini $\mathrm{Pu}$ memiliki evaluating yang baik, bisa dilihat dari hasil pekerjaan $\mathrm{Pu}$ sampai pada kesimpulan.

\section{Subjek Bergaya Kognitif Field Independent \\ Indikator Awareness}

Pada indikator metakognisi awareness dilihat dari subjek bisa menentukan apa yang diketahui dan ditanyakan.Pada tahap ini $\mathrm{AH}$ mempunyai awareness yang baik, bisa dilihat dari hasil pekerjaan $\mathrm{AH}$, namun $\mathrm{AH}$ masih kurang menyebutkan apa yang diketahui dari soal yaitu kolam tersebut berbentuk balok.

\section{Indikator Regulating}

Pada indikator metakognisi regulating dilihat dari subjek bisa menentukan rencana dan melaksanakan rencana tersebut.Pada tahap ini subjek AH mempunyai regulating yang sangat baik, AH bisa mengatur rencana dan melaksanakan rencana tersebut dengan baik dan benar.

\section{Indikator Evaluating}

Pada indikator metakognisi evaluating bisa dilihat dari subjek dapat memeriksa kembali jawaban yang telah dikerjakan dan bisa menari kesimpulan dari jawaban yang sudah ada.Pada tahap ini subjek AH mempunyai evaluating yang kurang baik karena AH hanya memeriksa kembali jawabannya tanpa sampai pada kesimpulan. Bisa dilihat pada hasil pekerjaan $\mathrm{AH}$.

Berdasarkan pada indikator metakognisi dalam pemecahan masalah penelitian ini menunjukan bahwa subjek-subjek penelitian belum mampu menunjukkan 
secara penuh indikator metakognisi dalam pemecahan masalah, masing-masing subjek hanya menunjukkan beberapa/ sebagian indikator dari proses metakognisi,yang lebih lengkapnya akan dijelaskan sebagai berikut:

1) Kelompok Gaya Kognitif field dependent (FD)

Setelah dilaksanakan analisis pada jawaban subjek $\mathrm{FD}(\mathrm{Pu})$ diperoleh hasil rincian proses metakognisi dalam pemecahan masalah.

Pada indikator awareness subjek $\mathrm{Pu}$ belum mampu menjelaskan apa yang diketahui, namun subjek mampu menyebutkan apa yang ditanyakan dari soal. Selanjutnya pada indikator regulating subjek $\mathrm{Pu}$ mampu mengatur rencana dan melaksanakan rencana pada pemecahan masalah dngan baik dan benar. Sedangkan pada indikator Evaluating subjek $\mathrm{Pu}$ mampu memeriksa kembali jawaban yang telah dikerjakan.

Temuan penelitian ini sesuai dengan penelitian olehNgilawajan (2013), yang menunjukkan bahwa subjek dengan gaya kognitif field dependent kurang baik dalam langkah memahami masalah dan kurang memahami konsep. Hal ini diperkuat dengan pernyataan dari Witkin (1997) yang menyebutkan subjek dengan gaya kognitif field dependent cendrung menyelesaikan soal dengan mengikuti tujuan yang sudah ada.
2) Gaya Kognitif field independent

(FI)

Setelah dilaksanakan analisis pada jawaban subjek FD (AH) diperoleh hasil, yaitu rincian proses metakognisi dalam pemecahan masalah.

Pada indikator awareness subjek mampu menyebutkan informasi apa yang bisa diketahui dan permasalahan apa yang ditanyakan. Selanjutnya pada indikator regulating subjek mampu mengatur rencana dan melaksanakan rencana dengan baik dan benar. Pada indikator evaluating subjek belum mampu memeriksa kembali jawaban yang sudah dikerjakan.

Temuan penelitian ini sesuai dengan penelitian oleh Ngilawajan (2013), yang menyatakan bahwa subjek dengan gaya kognitif field independent memahami masalah lebih baik dan menunjukan pemahaman yang baik terhadap konsep. Hal ini diperkuat oleh Witkin (1997) yang menyebutkan subjek dengan gaya kognitif field independent cenderung mengerjakan soal dengan pemikiran sendiri tanpa mengikuti cara/ petunjuk penyelesaian sebelumnya.

\section{KESIMPULAN DAN SARAN}

Kesimpulan yang dapat ditarik dari pembahasan yang sudah dipaparkan sebelumnya antara lain yaitu: 
(1) Proses metakognisi siswa kelompok gaya kognitif FD dalam pemecahan masalah matematika adalah sebagai berikut: Pada indikator awareness dapat dilihat bahwa $\mathrm{Pu}$ sudah mampu menyebutkan apa yang di ketahui dan ditanyakan dari soal secara langkap, namun pada tahap ini subjek Pu keliru dalam menuliskan apa yang diketahui. Pada indikator regulating subjek Pu sudah mampu menentukan rencana dan melaksanakan rencana dengan baik dan benar sampai pada penarikan kesimpulan. Pada indikator evaluating subjek $\mathrm{Pu}$ sudah bisa memeriksa kembali jawaban yang sudah di kerjakan dengan baik.

(2) Proses metakognisi siswa kelompok gaya kognitif FI dalam pemecahan masalah matematika adalah sebagai berikut: Pada indikator awareness subjek $\mathrm{AH}$ sudah mampu menyebutkan halhal yang diketahui dan ditanyakan dengan baik. Pada indikator regulating subjek $\mathrm{AH}$ mampu mengatur rencana dan melaksanakan rencana dengan baik dan benar. Pada indikator evaluating subjek $\mathrm{AH}$ belum mampu memeriksa kembali jawaban yang sudah dikerjakan namun belum sampai pada penarikan kesimpulan.

\section{Daftar Pustaka}

Balchin, T. dan Jackson, N. 2009. Developing

Students'
Creativity: Importance of Creativity Styles. Diunduh dari

http://78.158.56.101/archiv e/palatine/files/1002.pdf.

Murti, H.A.S. 2011. Metakognisi danTheory of Mind (ToM). Jurnal Psikologi Pitutur, 1(2): 53-64.

Ngilawajan, D.A. 2013. Proses Berpikir Siswa SMA dalamMemecahkan Masalah Matematika Materi Turunan Ditinjau dari Gaya Kognitif Field Independent dan Field Dependent. Jurnal Pedagogia, 2(1): 71-83.

Purnomo, Dwi. 2017. Karakterisasi Proses Metakogni Mahasiswa Matematika dalam Menyelesaikan Masalah Matematis. Disertasi (online). Program Pascasarjana Universitas Negeri Malang

Saputro, Mahadi. 2011. Analisis Kemampuan Pemecahan Masalah Matematika Berdasarkan LangkahLangkah Polya Ditinjau dari Gaya Kognitif Siswa. Tesis. Surakarta: UNS.

Sugiyono. 2008. Memahami penelitian Kualitatif. Bandung: Alfabeta.

Witkin, H. A., Moore, C. A, Goodenough, D.R., dan Cox, P.W. 1977. Field Dependent and Field Independent Cognitive Style and Their ducational Implications. Reviews of Educational Research, 47, 1-64. 